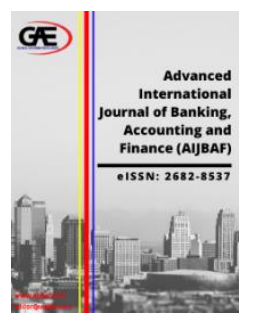

\author{
ADVANCED INTERNATIONAL JOURNAL OF \\ BANKING, ACCOUNTING AND FINANCE \\ (AIJBAF) \\ WWW.aijbaf.com
}

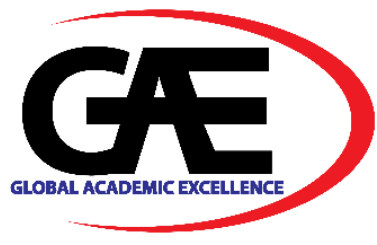

\title{
THE IMPACT OF COVID-19 ON THE FINANCIAL PERFORMANCE OF PN17 AND GN3 STATUS FIRMS: DOES IT ADD SALT INTO THE WOUND?
}

Wan Rozima Mior Ahmed Shahimi ${ }^{*}$, Ahmad Harith Ashrofie Hanafi ${ }^{2}$, Nurul Afidah Mohamad Yusof $^{3}$

1 Faculty of Business and Finance, Universiti Tunku Abdul Rahman, Perak, Malaysia

Email: rozima@utar.edu.my

2 Faculty of Business and Finance, Universiti Tunku Abdul Rahman, Perak, Malaysia

Email: harith@utar.edu.my

3 Faculty of Business and Finance, Universiti Tunku Abdul Rahman, Perak, Malaysia

Email: afidahj@utar.edu.my

* Corresponding Author

\section{Article Info:}

Article history:

Received date: 21.03 .2021

Revised date: 19.04.2021

Accepted date: 01.05.2021

Published date: 15.06 .2021

\section{To cite this document:}

Shahimi, W. R. M. A., Hanafi, A. H A., \& Yusof, N. A. M. (2021). The Impact of Covid-19 on The Financial Performance of PN17 and GN3 Status Firms: Does It Add Salt Into The Wound? Advanced International Journal of Banking, Accounting, and Finance, 3 (7), 47-58

DOI: 10.35631 /AIJBAF.37004

This work is licensed under $\underline{\text { C BY } 4.0}$

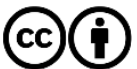

Abstract:

The Covid-19 pandemic has brought about major changes to the Malaysian economic landscape in terms of productivity level, investment, and household spending. Nonetheless, the unprecedented presence of Covid-19 has caused an unexpected level of disruption to firms from a liquidity and leverage perspective that impacts financial performance. This study focused on financially distressed firms classified under PN17 and GN3 by Bursa Malaysia. Hence, the aim of this study is to examine the impact of liquidity, leverage, and the Covid-19 pandemic period on the financial performance of financially distressed firms in Malaysia which are classified as PN17 and GN3 firms. By using liquidity ratios, financial leverage ratios, and a dummy variable of Covid19 , the result showed that the current ratio, net working capital, and debt ratio were found significant to affect the financial performance. Meanwhile, there is no significant evidence to support that the Covid-19 pandemic has an impact on the performance of financially distressed firms. The finding indicates that the financially distressed firm's financial performance was purely due to bad management practices, and not contributed by the Covid-19 pandemic.

Keywords:

Financial Performance, Liquidity, Financial Leverage, PN17 and GN3, Covid19 Pandemic 


\section{Introduction}

Since independence, Malaysia has successfully diversified its economy which was initially based on agriculture and commodities into an economy focusing on the manufacturing and services sectors (World Bank, 2020). Malaysia's economy is ranked the 6th largest in Southeast Asia and the 39th largest economy in the world (Amin, 2020). However, there is no denying that Malaysia has gone through several episodes of financial crises (Asian and Global), political crisis, the fall in global oil prices and China's economic slowdown which have put pressure on its economy.

Most recent, the Covid-19 pandemic has brought about major changes to the Malaysia's economic landscape in terms of productivity levels, investment and household spending. Malaysia's gross domestic product (hereafter GDP) recorded a sharp decline of $-17.1 \%$ with unemployment rate rose to $5.1 \%$ in the second quarter of 2020, the worst since 1998. On 13 November 2020, Bank Negara Malaysia (BNM) and the Department of Statistics Malaysia (DOSM) stated that in the third quarter, GDP showed a smaller decline of $-2.7 \%$ indicating a recovery point from the previous quarter. The recovery of the Malaysia's economic performance can be seen through the regulatory measures announced by government such as the implementation of various phases of the Movement Control Order (MCO) in dealing with the spread of the Covid-19, the reopening economic activities in stages and the permission for interstate travel for Malaysians (DOSM, 2020).

Ozili (2020) explained that the Covid-19 pandemic has led to the closure of financial markets and corporate activities. In addition, the uncertainty over the Covid-19 cases influenced investment decisions by investors which led to higher volatility in the stock market. There are recent literatures examining the effect of Covid-19 on stock price and economy (e.g. Hadiwardoyo, 2020; Lee et al., 2020; Ozili, 2020). Yet, literatures examining the effect of Covid-19 on firm performance are still limited. Undoubtedly, the profound circumstances developed by Covid-19 have caused unexpected levels of disruption to the firms such as decline of profits and financial performance in various types of businesses (Devi et al., 2020).

According to Bardia (2004), firms can be liquidated due to financial problems. Therefore, efficient liquidity management is very important for the sustainability of a firm (Ali et al., 2018; Mohammed et al., 2020). Evidence from previous studies suggested that firm liquidity affected the financial performance (Ali et al., 2018; Bardia, 2004; Ramlan \& Nodin, 2018; Rehman et al., 2015; Ehiedu, 2014; Zaid et al., 2014). There are however mixed results on the empirical evidence of liquidity relationship with firm's financial performance. From another perspective, Ivo and Anyanwaokoro (2019) claimed that leverage is the most important factor that can affect financial performance. During the economic boom, financial leverage benefits the financial performance but in the event of an economic downturn, financial leverage will adversely affect the firm's financial performance (Ahmad et al., 2015). The existing literatures offer mixed perspectives on how leverage might influence financial performance (Ramlan \& Nodin, 2018; Nadeem et al., 2015; Enekwe et al., 2014; Khatab et al., 2011; Yoon \& Jang, 2005). It remains inconclusive on how liquidity and leverage will affect financial performance at the time of Covid-19 as the literatures covering this scope are very limited (e.g. Aifuwa et al., 2020; Devi et al., 2020; Kroeger et al., 2020; Shen et al., 2020).

Endri et al. (2020) cited that financial analysis is useful for determining the financial performance and financial condition of a firm in avoiding the risk of bankruptcy. Financial Copyright (C) GLOBAL ACADEMIC EXCELLENCE (M) SDN BHD - All rights reserved 
Volume 3 Issue 7 (June 2021) PP. 47-58

DOI 10.35631/AIJBAF.37004

ratios are useful to differentiate the distressed and non-distressed firms. This financial ratio analysis is able to provide information on the financial status of firms to benefit investors in making their investment decisions. Financially distressed firms in Malaysia are classified as PN17 (Practice Note 17) and GN3 (General Note 3), which involves firms that are listed on the Bursa Malaysia's Main Market and ACE Market, respectively. PN17 firms must submit proposals to the Agreement Board to restructure and restore their firms in order to maintain their listing in Bursa Malaysia. In the wake of Covid-19, Bursa Malaysia on 17 April 2020 had temporarily relaxed the classification of PN17 and GN3 (General Note 3) on firms under these criteria effective from 17 April 2020 to 30 June 2021 by giving more time for them to regulate their financial position (Tan, 2020).

According to Kok (2010), there are investors holding stocks in PN17 firms who are not aware that those firms had been listed as PN17. The PN17 status firms are known as the firms that are not well managed and have poor management practices (Kim-Soon et al., 2013). However, with the new Covid-19 pandemic disruption, it raises the question as to whether this pandemic also has a hand in the distressed firms' financial position. Previous studies have not explored this scope. Therefore, this study intends to fill this gap in the literature. Hence, the main objective of this study is to examine the impact of liquidity, leverage, and Covid-19 pandemic period on financial performance of the financially distressed firms in Malaysia which are classified as PN17 and GN3 firms. Therefore, this study is critical to provide relevant information to the body of knowledge on the financial performance of these firms during the Covid-19 pandemic as the information is hard to find specifically related to the topic.

\section{Literature Review}

\section{Liquidity and Financial Performance}

Liquidity reflects a firm's ability to meet short-term fund needs. Firms are said to be more profitable if short-term fund needs are derived from the high value of current assets rather than external debt (Ahmad, 2016). According to Bardia (2004), the financial performance of any firm is assessed by the efficiency of liquidity management. Several studies have examined on liquidity (current ratio and quick ratio) and financial performance in various industries or countries. A significant positive effect between liquidity and profit (return on assets, hereafter ROA) was reported in the study of Ali and Bilal (2018) and Ali et al. (2018) in Jordan, and Ehiedu (2014) in Nigeria. Madushanka and Jathurika (2018) and Kanga and Achoki (2017) and also concluded the similar results in their study covering Kenya and Sri Lanka respectively by using both ROA and return on equity (hereafter ROE) as a measure of profitability. On the other hand, Jepkemoi (2017) found that firm's liquidity was insignificantly positive towards ROA and ROE.

In the Malaysian context, Ramlan and Nodin (2018) and Zaid et al. (2014) asserted that liquidity has a significant positive relationship with the financial performance measured by ROA. However, in a recent study, Mohammed et al. (2020) stated the opposite whereby liquidity is not a significant variable to indicate a firm's profitability. On the contrary, Noor and Lodhi (2015) found negative impact of liquidity on firm's profitability (ROA and ROE) in selected sample on Karachi stock exchange which indicated that the lesser liquidity, the more the profitability. A study by Rehman et al. (2015) revealed a negative but insignificant relationship between the ROA and liquidity, while ROE had insignificant relationship with liquidity in the context of Saudi Arabia. The findings from Priya and Nimalathasan (2013) 
Volume 3 Issue 7 (June 2021) PP. 47-58

DOI 10.35631/AIJBAF.37004

suggested that there was a significant negative relationship between liquidity and profitability in Sri Lanka.

From another point of view, some authors asserted that liquidity does not affect financial distress (e.g. Oktasari, 2020; Rohmadini et al., 2018; Cinantya \& Merkusiwati, 2015). According to Oktasari (2020), current assets are used to finance the liabilities so any amount of liquidity will not affect the possibility of the firm experiencing financial distress. Meanwhile, Curry and Banjarnahor (2018) and Wahono et al. (2017) indicated that liquidity has a negative effect on financial distress. Other researchers such as Almansour (2015) and Bunn and Redwood (2003) concluded that liquidity has insignificant negative association to the financial distress. The argument is that the higher the liquidity, the lower the probability of a firm's bankruptcy. Some studies are consistent with each other in their findings and some found contradiction in the relationship between liquidity and financial distress firm.

\section{Leverage and Financial Performance}

Leverage refers to the extent to which firms use their borrowings to increase profitability (Alkhatib, 2012). High leverage can motivate financial managers to improve the performance of their firms but can also increase agency costs. Thus, leverage can affect a firm's value positively or negatively, since it magnifies returns and risk (Ivo \& Anyanwaokoro, 2019). Earlier study by Barclay, Smith and Watts (1995) showed significant positive correlation between the leverage measured debt ratio and profitability (ROA and ROE). In Pakistan, Khatab et al. (2011) also documented the same result when using ROA as the representation of a firm's performance. It is consistent with Nadeem et al. (2015) who found positive and significant association between profitability (ROA \& ROE) and financial leverage (debt to equity). Under the same proximity, Rehman (2013) showed that the leverage (debt ratio) positively correlates with ROA but negatively associated to ROE. Nonetheless the result in Nguyen et al. (2019) study was the opposite of Rehman (2013) whereby financial leverage (debt to equity) negatively impacts ROA, but displays a positive impact on ROE for real estate firms in Vietnam.

Some researchers reported negative relationship between leverage and profitability of the firms. Earlier, Yoon and Jang (2005) found negative relationship between ROE and leverage measured by debt ratio leading to the conclusion that firms with higher debt rates are less profitable. Another negative result was found by Kaumbuthu (2011) for the industrial sector in the Nairobi Securities Exchange. In Iran, Pouraghajan et al. (2012) found a significant negative relationship between the debt ratio and the ROA and ROE. In addition to that, Enekwe et al. (2014) also indicated the negative impact of financial leverage (debt ratio and debt-equity ratio) on financial performance (ROA) in Nigeria. Most recent, Ivo and Anyanwaokoro (2019) in their study revealed that leverage (debt ratio and debt to equity) had negative insignificant effect on ROA of manufacturing firms in Nigeria, where he explained that an increase in leverage could lower the ROA. A study in Malaysia by Ramlan and Nodin (2018) confirmed that the leverage represented by the debt ratio had a significant relationship with firm's performance (ROA). Most recent, Mohammed et al. (2020) found leverage (debt to equity) had a significant negative relationship with the firm's profitability (ROA and ROE) of the listed oil and gas firms.

From the financial distress context, some researchers pointed out that leverage has significant effect on the firm's financial distress (e.g. Rohmadini et al., 2018; Muhtar \& Aswan, 2017; Copyright (C) GLOBAL ACADEMIC EXCELLENCE (M) SDN BHD - All rights reserved 
Volume 3 Issue 7 (June 2021) PP. 47-58

DOI 10.35631/AIJBAF.37004

Simanjuntak et al., 2017). The positive relationship between leverage and financial distress was reported in a research conducted by Andre (2013). On the contrary, Ginting (2017) indicated a significant negative influence of leverage on the financial distressed firms implying that the firms with high leverage are not necessarily categorized as the firms with financial distress, and vice versa because high firm liabilities are covered with high assets owned as well. Recently, Oktasari (2020) also proclaimed that leverage does not have a significant effect on the likelihood of financial distress. According to him, the higher the funds provided by creditors with firm owners, the lower the likelihood of financial distress.

\section{Outbreak and Financial Performance}

Past literatures have shown that public catastrophe and global concern can affect a firm's performance. However, researches on the disastrous effects of these outbreaks are not comprehensive. A previous study conducted by Chen et al. (2007) showed that the SARS epidemic had significantly damaged the performance of hotels in Taiwan which saw a sharp decline in stock prices during the outbreak period. Chen (2010) expanded the study by looking at corporate performance (ROA and ROE) of the same industry in Taiwan. The growth rate of total foreign tourist arrivals and GDP had a positive impact on profitability, but the size was found to be negatively related to ROA and ROE.

With regard to the Covid-19 outbreak, Shen et al. (2020) investigated the impact of Covid-19 on firm's performance in various provinces and industries in China. With ROA as a dependent variable and various elements of size, leverage, growth rate, and cash flow as the independent variables, the results showed that the pandemic indeed has led to the reduction of income consequently resulting in lower performance. Meanwhile, Aifuwa et al. (2020) who studied the effect of the Covid-19 on the performance of private businesses in Nigeria revealed that the pandemic has harmed the financial performance, as measured by ROA. They recommended that the government should include private businesses in its stimulus packages in helping them to sustain their businesses and operation during this tough time. Devi et al. (2020) who examined the impact of the Covid-19 pandemic on financial performance listed on the Indonesia stock exchange drew two conclusions from the study; firstly, there was an increase in leverage (debt to equity) and but a decrease in liquidity (current ratio) and profitability (ROA) during the Covid-19 pandemic. Secondly, no significant difference was found in the liquidity and leverage, however there was a significant difference in the profitability before and during the pandemic.

Nonetheless, Hafidzi and Qomariah (2020) revealed a positive relationship between corporate social responsibilities (hereafter CSR), ROA and share prices in Indonesian manufacturing firms during Covid-19. They explained that investors are confident with firms that show consistent profits, higher stock prices and better ability to allocate CSR exposure costs from operating income. Through the sensitivity analysis on the Vietnamese non-financial firms, Kroeger et al. (2020) highlighted that smaller domestic firms are predominantly vulnerable than to regional firms to have Covid-19 impact on profitability (EBIT), liquidity (cash, current ratio) and leverage (interest coverage ratio). Although larger firms were more profitable but also highly leveraged and lower liquidity in the wake of the pandemic.

Although, there are mixed findings from previous literature, three hypotheses are proposed in order to investigate the impact of liquidity and leverage on financial performance as follows: 
Volume 3 Issue 7 (June 2021) PP. 47-58 DOI 10.35631/AIJBAF.37004

H1 - There is a significant impact of liquidity on the financial performance of the financially distressed firms.

$\mathrm{H} 2$ - There is a significant impact of financial leverage on financial performance of the financially distressed firms.

H3 - There is a significant impact of Covid-19 pandemic period on the financially distressed firms.

\section{Empirical Design}

\section{Sample Data}

This study used the financial information of the financial distressed firms listed under Practice Note 17 (PN17) and (GN3) by Bursa Malaysia as at 31 October 2020 as the study sample. There is a total of 24 firms listed under both lists. This study used quarterly panel data starting from 2019Q2 to 2020Q3. The financial information of all firms were collected from the Bloomberg Terminal, and were used to calculate the financial ratios.

\section{Empirical Model}

In order to examine the impact of liquidity, leverage, and Covid-19 pandemic period on financial performance of financially distressed firms in Malaysia, this study used panel regression analysis based on the following regression model:

$$
\text { ROA }=\alpha+\beta_{1} \text { Liquidity Ratio }+\beta_{2} \text { Leverage Ratio }+\beta_{3} \text { Covid19 }+\varepsilon
$$

Where $\alpha$ represents intercept while $\beta$ represents the coefficient for each selected variable. The dependent variable in this study is firm performance, which is represented by return on assets (ROA). It is an accounting measure which indicates how well a firm is using its assets to generate profits (Oktasari, 2020; Curry \& Banjarnahor, 2018; Rehman et al., 2015; Ehiedu, 2014). Meanwhile, the independent variables in this study are liquidity, financial leverage, and Covid19 period. Similar to previous studies by Mohammed et al. (2020) and Bardia (2004), two ratios were used to represent the firm's liquidity position i.e., current ratio (CR) and net working capital ratio (WC). Meanwhile, debt ratio (DR) and debt to equity ratio (DTE) were used to represent firm's financial leverage elements of the firms (Mohammed et al., 2020; Ivo \& Anyanwaokoro, 2019). A binary dummy variable was used to account for the Covid-19 period, which equals 1 for post-WHO pandemic announcement (11 March 2020); and 0 otherwise. Table 1 presents the operationalisation of the variables used in this study.

Table 1: Operationalisation of the Variables

\begin{tabular}{ll}
\hline Variable & Operationalisation \\
\hline ROA & Net profit / Total Assets \\
CR & Current Assets / Current Liabilities \\
WC & Current Assets - Current Liabilities \\
DR & Total Liabilities / Total Assets \\
DTE & Total Liabilities / Total Assets \\
Covid19 & $1=$ Post-WHO pandemic announcement; $0=$ otherwise \\
\hline
\end{tabular}




\section{Results}

This section starts by analysing the data collected based on descriptive analysis which includes the reporting of mean, standard deviation, minimum and maximum value of the variables. Table 2 shows the results of descriptive analysis.

Table 2: Descriptive Analysis

\begin{tabular}{lrrrr}
\hline Variable & Mean & Std. Dev & Min. & Max. \\
\hline ROA & -1.518 & 13.180 & -155.400 & 4.655 \\
CR & 1.250 & 2.359 & 0.003 & 10.480 \\
WC & -23.220 & 170.300 & -318.700 & 593.400 \\
DR & 11.46 & 41.480 & 0.158 & 391.600 \\
DTE & -0.168 & 4.995 & -18.940 & 29.410 \\
Covid19 & 0.500 & 0.501 & 0.000 & 1.000 \\
\hline
\end{tabular}

Note: ROA represents return on assets, CR represents current ratio, WC represents net working capital, DR represents debt ratio, DTE represents debt to equity ratio, and Covid19 represents Covid-19 pandemic period.

Based on Table 2, ROA that represents dependent variable showed a mean value of -1.518 with standard deviation of 13.180. The variable had values between -155.400 and 4.655. CR had mean value of 1.250 and standard deviation of 2.359 with maximum value of 10.480 . WC recorded the mean value of -23.220 with standard deviation of 170.300 and ranged between 318.700 and 593.400. As for DR, the mean value was 11.460 while the standard deviation value was 41.480 with the maximum value of 391.600. DTE ratio representing the leverage ratio showed the mean value of -0.168 and standard deviation of 4.995 which fluctuated between 18.940 and 29.410. Lastly for dummy variable Covid-19, the mean value was 0.500 with standard deviation of 0.501 .

Next, the results from the panel regression analysis are presented in Table 3.

Table 3: Regression Analysis

\begin{tabular}{lrrrr}
\hline & Coefficient & Std. Error & t-ratio & \multicolumn{1}{c}{ p-value } \\
\hline Constant & 2.786 & 0.921 & 3.024 & $0.003^{* * *}$ \\
CR & -0.926 & 0.412 & -2.249 & $0.026^{* *}$ \\
WC & 0.011 & 0.006 & 1.886 & $0.061^{*}$ \\
DR & -0.276 & 0.013 & -20.87 & $0.000^{* * *}$ \\
DTE & -0.026 & 0.107 & -0.242 & 0.810 \\
Covid19 & -0.538 & 0.964 & -0.558 & 0.578 \\
\hline
\end{tabular}

Note: ROA represents return on assets, CR represents current ratio, WC represents net working capital, DR represent debt ratio, DTE represents debt to equity ratio, and Covid19 represents Covid-19 pandemic period. The asterisk symbol (*) on p-value represents statistically significant at a certain level; *** statistically significant at $1 \%$ level, $* *$ statistically significant at $5 \%$ level, and * statistically significant at $10 \%$ level

The result in Table 3 indicates that CR was negatively affecting the firm's performance and the result is statistically significant at $5 \%$ level. The finding suggests that as the financially distressed firm's liquidity increases, the firm's financial performance will decrease. As firm liquidity increases, it also indicates lower financing from current liability due to lower credit purchase of raw materials that lead to lower sales which will reduce the firm's profit and performance. It may also indicate that current assets are not utilised efficiently in order to generate more profits for the firm. This result is similar to the study by Noor and Lodhi (2015). However, the result showed that $\mathrm{WC}$ has a positive and significant effect on the financial Copyright $\odot$ GLOBAL ACADEMIC EXCELLENCE (M) SDN BHD - All rights reserved 
Volume 3 Issue 7 (June 2021) PP. 47-58

DOI 10.35631/AIJBAF.37004

performance of the financially distressed firm. This indicates that higher liquidity will help to increase the firm's performance. This is similar to previous study such as Ramlan and Nodin (2018) and Zaid et al. (2014) that also found significant positive relationship between liquidity and financial performance. The result obtained revealed that as firm's ability in meeting shortterm obligation is higher, the firm could obtain more short-term financing to finance their operation which will help to increase the firm's revenue as well as profit and improve firm's financial performance.

The result also showed that the DR which represents the leverage ratio recorded negative coefficient value with the significant level of $10 \%$. This indicates as financially distressed firm's leverage level increases, the firm's financial performance will drop due to higher financial cost that the firm need to bear, consequently reducing the firm's profit. This result is in line with the results found in the studies by Ivo and Anyanwaokoro (2019), Ramlan and Nodin (2018), Kaumbuthu (2011) and Yoon and Jang (2005). However, DTE which also represents the leverage ratio was found to be insignificant. The result is totally contradicted to the findings in the studies by Nadeem et al. (2015), Rehman (2013) and Khatab et al. (2011). This might indicate that the proportion of debt to equity has insignificant effect on the financial performance of the financially distressed firm.

Lastly, this study also included a dummy variable for Covid-19 period order to find the effect of pandemic period on the financial performance of financially distressed firm. The results indicates that the financial performance of financially distressed firms is not significantly affected by the pandemic period. Given the fact that these companies were already in a financially distressed position, it is plausible that there was little impact caused by all the social and economic restrictions imposed during the Covid-19 pandemic period. Hence, this result is found to contradict some other studies, e.g., Aifuwa et al. (2020) and Shen et al. (2020), which had examined the firm performance generally, without focusing on financially distressed firms.

\section{Conclusion}

This study examines the effect of liquidity, financial leverage, and Covid-19 pandemic period on financial performance of financially distressed firms in Malaysia. This study involved the financially distressed firms classified under PN17 and GN3 by Bursa Malaysia within the period of 2019Q2 to 2020Q3. Financial ratios such as liquidity ratio and leverage ratio were used as the independent variables in this study. As for Covid-19 pandemic period, this study used binary dummy variable which equals 1 for post-WHO pandemic announcement (11 March 2020); and 0 otherwise.

The result suggests that both the liquidity (CR and WC) and financial leverage position (DR) have a significant effect on the performance of the financially distressed firms. Meanwhile, there is no significant evidence to support that Covid-19 pandemic has an impact on the performance of the financially distressed firms. The finding in this study is consistent with Kim-Soon et al. (2013), whereby it can be concluded that the financially distressed firm's financial performance was purely due to bad management practices, and not contributed by the Covid-19 pandemic.

There are some limitations in this study. Firstly, the duration of this study was relatively short. Future research could lengthen the duration of the study to comprehensively assess the impact of liquidity and financial leverage on financial performance as Covid-19 is still a global Copyright (C) GLOBAL ACADEMIC EXCELLENCE (M) SDN BHD - All rights reserved 
Volume 3 Issue 7 (June 2021) PP. 47-58

DOI 10.35631/AIJBAF.37004

concern. Secondly, only two ratios were tested for each liquidity ratio and leverage ratio. It is therefore recommended for further research to carry out more in-depth research by including other ratios and other elements such as firm size and growth rate for better comparison.

\section{References}

Ahmad, R. (2016). A study of relationship between liquidity and profitability of standard charterd bank Pakistan: Analysis of financial statement approach. Global Journal of Management and Business Research: C Finance, 16(1). 77-82.

Ahmad, N., Salman, A., \& Shamsi, A. (2015). Impact of financial leverage on firms profitability: An investigation from cement sector of Pakistan. Research Journal of Finance and Accounting, 6(7), 75-80.

Aifuwa, H. O., Saidu, M., \& Aifuwa, S. A. (2020). Coronavirus pandemic outbreak and firms performance in Nigeria. Management and Human Resource Research Journal, 9(4), $15-25$.

Ali, M., Al-Rdaydeh, M., Al-Shannag, F., \& Odeh, M. (2018). Factors affecting the corporate performance: Panel data analysis for listed firms in Jordan. Academy of Accounting and Financial Studies Journal, 22(6), 1-10.

Ali, M., \& Bilal, M. E. (2018). Determinants of financial performance in the industrial firms: Evidence from Jordan. Asian Journal of Agricultural Extension, Economics and Sociology, 22(1), 1-10.

Alkhatib, K. (2012). The determinants of leverage of listed companies. International Journal of Business and Social Science, 3(24), 78-83.

Almansour, B. Y. (2015). Empirical model for predicting financial failure. American Journal of Economics, Finance and Management, 1(3), 113-124. http://www.publicscienceframework.org/journal/ajefm

Amin, A. M. (2020, December 18). Malaysia deserves a seat to serve. New Straits Times. https://www.nst.com.my/opinion/columnists/2020/12/650308/malaysia-deserves-seatserve

Andre, O. (2013). The effect of profitability, liquidity and leverage in predicting financial distress: Empirical study of various companies listed on BEI. Jurnal Akuntansi, 1(1).

Barclay, M. J., Smith, C. W., \& Watts, R. L. The determinants of corporate leverage and dividend policies. Journal of Applied Corporate Finance, 7(4).

Bardia, S. (2004). Liquidity management (A case study on TISCO). The Management Accountant, 463-467.

Bunn, P., \& Redwood, V. (2003). Firm accounts based modelling of business failures and the implications for financial stability. Bank of England Quarterly Bulletin, 43(4), 462-462.

Chen, M.-H. (2010). The economy, tourism growth and corporate performance in the Taiwanese hotel industry, Tourism Management, 31(5), 665-675.

Chen, M.-H., Jang, S. S., \& Kim, W. G. (2007). The impact of the SARS outbreak on Taiwanese hotel stock performance: An event-study approach. International Journal of Hospitality Management, 26(1), 200-212.

Cinantya, I., \& Merkusiwati, N. (2015). Pengaruh corporate governance, financial indicators, dan ukuran perusahaan pada financial distress. E-Jurnal Akuntansi, 10(3), 897-915.

Curry, K., \& Banjarnahor, E. (2018). Financial distress pada perusahaan sektor properti go public di Indonesia. Seminar Nasional, 1(2), 207-221.

Department of Statistics Malaysia. (2020, November 13). Malaysia economic performance third

quarter

2020.

https://www.dosm.gov.my/v1/index.php?r=column/cthemeByCat\&cat=100\&bul_id=

Copyright $\odot$ GLOBAL ACADEMIC EXCELLENCE (M) SDN BHD - All rights reserved 
Volume 3 Issue 7 (June 2021) PP. 47-58

DOI 10.35631/AIJBAF.37004

ZIRNZVRDUmNzRFFQQ291ZXJoV0UxQT09\&menu_id=TE5CRUZCblh4ZTZMO DZIbmk2aWRRQT09

Devi, S., Warasniasih, N. M. S., Masdiantini, P. R \& Musmini, L. S. (2020). The impact of Covid-19 pandemic on the financial performance of firms on the Indonesia stock exchange. Journal of Economics, Business, and Accountancy Ventura, 23(2), 226-242. http://dx.doi.org/10.14414/jebav.v23i2.2313

Ehiedu, V. C. (2014). The impact of liquidity on profitability of some selected companies: the financial statement analysis (FSA) approach. Research Journal of Finance and Accounting, 5(5), 81-90.

Endri, E., Sumarno, A., \& Saragi, H. (2020). Analysis of financial performance: Evidence from food and beverage companies in Indonesia. International Journal of Advanced Science and Technology, 29(5), 4199-4208.

Enekwe, C. I., Agu, C. I., \& Eziedo, K. N. (2014). The effect of financial leverage on financial performance: Evidence of quoted pharmaceutical companies in Nigeria. IOSR Journal of Economics and Finance, 5(3), 17-25. http://www.iosrjournals.org/iosrjef/papers/vol5-issue3/C0521725.pdf

Ginting, M.C., (2017). Effect of current ratio and debt to equity ratio (DER) on financial distress in property \& real estate companies on the Indonesia stock exchange. Management Journal, 3(2), 37-44.

Hadiwardoyo, W. (2020). Kerugian Ekonomi Nasional Akibat Pandemi Covid-19. Baskara Journal of Business and Entrepreneurship, 2(2), 83-92. https://jurnal.umj.ac.id/index.php/baskara/article/view/6207/4026

Hafidzi, A. H., \& Qomariah, N. (2020). Impact of corporate social responsibility on stock prices through financial performance in manufacturing companies listed on the IDX in the Covid era 19. International Journal of Advanced Research in Engineering \& Technology 11(11), 1510-1520.

Ivo, M. S., \& Anyanwaokoro, M. (2019). Relating financial leverage to corporate performance: A case of cement manufacturing firms in Nigeria. South Asian Journal of Social Studies and Economics, 3(4), 1-14. https://doi.org/10.9734/sajsse/2019/v3i430114

Jepkemoi, E. (2017). Determinants of bank's profitability in Kenya. A Project Report Submitted to the Chandaria School of Business in Partial Fulfillment of the Requirement for the Degree of Masters in Business Administration (MBA). http://erepo.usiu.ac.ke/11732/3635

Kanga, O. S., \& Achoki, G. (2017). Liquidity and financial performance in agricultural firms listed in the nairobi securities exchange in Kenya. International Journal of Business and Social Science, 7(7), 57-65.

Kaumbuthu, A. J. (2011). The relationship between capital structure and financial performance: A study of firms listed under industrial and allied sector at the NSE. MBA Dissertation, University of Nairobi). http://erepository.uonbi.ac.ke

Khatab, H., Masood, M., Zaman, K., Saleem, S., \& Saeed, B. (2011). Corporate governance and firm performance: A case study of Karachi stock market. International Journal of Trade, Economics and Finance, 2(1), 39-43.

Kim-Soon, N., Mohammed, A. A. E., \& Agob, F. K. M. (2013). A study of financial distress companies listed in the Malaysian stock exchange using financial liquidity ratios and Altman's model. European Journal of Scientific Research, 114(4), 513-525.

Kok, H.O. (2010, July 14). What is a PN17 firm? Do you sell or buy its shares. The Star. https://www.thestar.com.my/business/business-news/2010/07/14/what-is-a-pn17-firmdo-you-sell-or-buy-its-shares/

Copyright $\odot$ GLOBAL ACADEMIC EXCELLENCE (M) SDN BHD - All rights reserved 
Volume 3 Issue 7 (June 2021) PP. 47-58 DOI 10.35631/AIJBAF.37004

Kroeger, T., Nguyen, A. T. N., Zhang, Y. S., Thuy, P. D., Minh, N. H., \& Tuan, D. D. (2020). Corporate vulnerabilities in Vietnam and implications of Covid-19 (Paper No. WP/20/260). IMF Working Paper.

Lee, K. Y., Jais, M., \& Chan, C. (2020). Impact of Covid-19: Evidence from Malaysian Stock Market. International Journal of Business and Society, 21(2), 607-628. http://www.ijbs.unimas.my/images/repository/pdf/Vol21-no2-paper7.pdf

Madushanka, K. H. I., \& Jathurika, M. The impact of liquidity ratios on profitability (with special reference to listed manufacturing companies in Sri Lanka). International Research Journal of Advanced Engineering and Science, 3(4), 157-161.

Mohammed, N. F., Puat, S. A., Amirrudin, M. S., \& Hashim, A. (2020). Leverage, liquidity and profitability ratios: Accountability of Malaysian listed oil and gas firms. Humanities and Social Sciences Reviews, 8(2), 941-947. https://doi.org/10.18510/hssr.2020.82104

Muhtar, M., \& Aswan, A. (2017). Influence of financial performance against the occurrence of financial distress conditions in telecommunications companies in Indonesia. Journal of Business Management and Information Hasanudin University, 13(3).

Nadeem, M., Ahmad, R., Ahmed, A., Ahmad, N., Batool, S.R., \& Khalil-Ur-Rehman. (2015). The effect of leverage on financial health of the firms: A study from cement industry of Pakistan. Industrial Engineering Letters, 5(5), 123-126.

Nguyen, V. C., Nguyen, T. N. L., Tran, T. T. P., \& Nghiem, T. T. (2019). The impact of financial leverage on the profitability of real estate companies: A study from Vietnam stock exchange. Management Science Letters, 9(2019), 2315-2326.

Noor, A., \& Lodhi, S. (2015). Impact of liquidity ratio on profitability: An empirical study of automobile sector in Karachi. International Journal of Scientific and Research Publications, 5(11), 639-646.

Oktasari, D. P. (2020). The effect of liquidity, leverage and firm size of financial distress. East African Scholars Multidisciplinary Bulletin, 3(9), 293-297.

Ozili, P. (2020). Covid-19 in Africa: Socio-economic impact, policy response and opportunities. International Journal of Sociology and Social Policy. https://doi.org/10.1108/IJSSP-05-2020-0171

Pouraghajan, A., Malekian, E., Emamgholipour, M., Lotfollahpour, V., \& Bagheri, M. M. (2012). The relationship between capital structure and firm performance evaluation measures: Evidence from the Tehran stock exchange. International Journal of Business and Commerce, 1(9), 166-181.

Priya, K., \& Nimalathasan, B. (2013), Liquidity management and profitability: A case study of listed manufacturing companies in Sri Lanka. International Journal of Technological Exploration and Learning, 2(4), 135-151.

Ramlan, H., \& Nodin, M. (2018). The effect leverage, liquidity and profitability on the companies performance. Journal of Humanities, Language, Culture and Business, 2(7), 9-15.

Rehman, M. Z., Khan, M. N., \& Khokhar, I. (2015). Investigating liquidity-profitability relationship: Evidence from companies listed in Saudi stock exchange (Tadawul). Journal of Applied Finance and Banking, 5(3), 159-173.

Rohmadini, A., Saifi, M., \& Darmawan, A. (2018). Effect of profitabilias, liquidity, and leverage on financial distress: Study of food \& beverage companies listed on the Indonesia stock exchange period 2013-2016. Journal of Business Administration, 61(2). 
Volume 3 Issue 7 (June 2021) PP. 47-58 DOI 10.35631/AIJBAF.37004

Shen, H., Fu, M., Pan, H., Yu, Z., \& Chen, Y. (2020). The impact of the Covid-19 pandemic on firm performance. Emerging Markets Finance and Trade, 56(10), 2213-2230. https://doi.org/10.1080/1540496X.2020.1785863

Simanjuntak, C., Titik, F., \& Aminah, W. (2017). Pengaruh rasio keuangan terhadap financial distress (studi pada perusahaan transportasi yang terdaftar di bursa efek Indonesia. Akuntansi. https://doi.org/2355-9357.

Tan, R. (2020, April 17). More relief from SC. The Star. https://www.thestar.com.my/business/business-news/2020/04/17/more-relief-from-sc

Wahono, Mardani, \& Suproho. (2017). Pengaruh likuiditas leverage dan profitabilitas terhadap financial distress pada perusahaan transportasi yang terdaftar di bursa efek Indonesia (Bei) tahun 2011-2015. E-Jurnal Riset Manajemen, 179-190.

World Bank. (2020, April). Overview. https://www.worldbank.org/en/country/malaysia/overview

Yoon, E., \& Jang, S. (2005). The effect of financial leverage on profitability and risk of restaurant firms. Journal of Hospitality Financial Management, 13(1).

Zaid, N. A. M., Ibrahim, W. M. F. W., Zulqernain, N. S. (2014). The determinants of profitability: Evidence from Malaysian construction companies. Proceedings of 5th Asia-Pacific Business Research Conference 2014, Kuala Lumpur, Malaysia (pp1-13). 